\title{
INVESTIGATION OF CAPACITY FADE AND VOLTAGE DECAY IN Li-RICH CATHODE MATERIALS WITH DIFFERENT PHASE COMPOSITION
}

\author{
${ }^{1}$ Lidia PECHEN, 'Elena MAKHONINA, 'Vyacheslav VOLKOV, ${ }^{2,3}$ Alexander RUMYANTSEV, \\ ${ }^{2,3}$ Yury KOSHTYAL, ${ }^{1}$ Yury POLITOV, ${ }^{1}$ Vladislav PERVOV, ${ }^{1}$ Igor EREMENKO \\ ${ }^{1}$ Kurnakov Institute of General and Inorganic Chemistry, Russian Academy of Sciences, Moscow, \\ Russian Federation, lidia.s.maslennikova@gmail.com, elenamakhonina@mail.ru \\ 2 Ioffe Institute, Russian Academy of Sciences, Saint-Petersburg, Russian Federation, \\ yury.koshtyal@gmail.com
}

${ }^{3}$ Peter the Great Saint-Petersburg Polytechnic University, Saint-Petersburg, Russian Federation https://doi.org/10.37904/nanocon.2019.8622

\begin{abstract}
Lithium-rich oxides with different compositions are synthesized by coprecipitation method and tested as cathode materials for lithium-ion batteries (LIBs). The paper presents research into the degradation processes: capacity and voltage fade during cycling life. The lithium mobility is known to make one of the major contributions to LIBs lifetime. Therefore, galvanostatic intermittent titration (GITT) is provided to estimate lithium-ion diffusion coefficients $\left(D_{L i+}\right)$. We also calculate ohmic and polarization resistance values. There is shown the influence of the structural transformation of lithium-rich oxides on their kinetic parameters. We make an assumption about the optimal composition of such cathode materials for good electrochemical properties.
\end{abstract}

Keywords: Lithium-ion battery, Li-rich cathodes, lithium-ion diffusion, electrochemical properties

\section{INTRODUCTION}

Today, we are surrounded by an abundance of portative devices and there is a widespread occurrence of hybrid-electric vehicles (HEVs) and all-electric vehicles (EVs). Electrical energy storage is also an essential task for energy development. To achieve required performances for future LIBs generation we need to prepare new positive electrode materials $[1,2]$.

In the early 2000s, Thackeray et al. [3-5] reported about integrated 'layered-layered' oxides (or Li-rich oxides) with notation $\mathrm{xLi}_{2} \mathrm{MnO}_{3} \cdot(1-\mathrm{x}) \mathrm{LiMO}_{2}$ as insertion electrode for LIBs. Primarily, those electrode materials were considered as $\mathrm{Li}_{2} \mathrm{MnO}_{3}$-stabilized $\mathrm{LiMO}_{2}$, as a result, $\mathrm{LiMO}_{2}$ was to have long-term cycling life. Later, the active research into Li-rich oxide synthesis was made because of high discharge capacities $(250-270 \mathrm{~mA} \mathrm{~h} / \mathrm{g})$ in the wide voltage range (to 4.6-4.8 V). However, apart from considerable capacity advantages of such oxides, it has some disadvantages: in particular, capacity fade and voltage decay during cycling [6,7]. Voltage and capacity during discharge can decrease whether on account that the internal resistance increases due to surface film formation, loss of the electric contact between particles and current collector or on account of changes in active material thermodynamic characteristics. The variation of lithium-ion diffusion coefficient $\left(D_{L i+}\right)$ in charge/discharge process is one of the important factors that can depend on a resistance increase and different structural transformations [8,9].

In the previous study, we investigated the influence of synthesis procedure and composition for Li-rich cathode materials on their electrochemical performances [10]. It was demonstrated that $0.35 \mathrm{Li}_{2} \mathrm{MnO}_{3} \cdot 0.65 \mathrm{LiMn}_{1 / 3} \mathrm{Ni}_{1 / 3} \mathrm{Co}_{1 / 3} \mathrm{O}_{2}$ has better cycling among other Li-rich compositions. To explain the results obtained, we have studied the cycling behavior of the above Li-rich oxide cathodes using galvanostatic intermittent titration. Diffusion coefficients $D_{L i+}$ and ohmic and polarization resistances at the different discharge cycles were estimated. 


\section{EXPERIMENTAL}

The coprecipitation method followed by a solid-state reaction with a lithium source was used to prepare Li-rich oxides with different phase compositions: $0.5 \mathrm{Li}_{2} \mathrm{MnO}_{3} \cdot 0.5 \mathrm{LiMn}_{1 / 3} \mathrm{Ni}_{1 / 3} \mathrm{Co}_{1 / 3} \mathrm{O}_{2}$ (LMR50), $0.35 \mathrm{Li}_{2} \mathrm{MnO}_{3} \cdot 0.65 \mathrm{LiMn}_{1 / 3} \mathrm{Ni}_{1 / 3} \mathrm{Co}_{1 / 3} \mathrm{O}_{2}$ (LMR35), $0.2 \mathrm{Li}_{2} \mathrm{MnO}_{3} \cdot 0.8 \mathrm{LiMn}_{1 / 3} \mathrm{Ni}_{1 / 3} \mathrm{Co}_{1 / 3} \mathrm{O}_{2}$ (LMR20) in accordance with $[11,12]$ works. The first synthesis step was coprecipitation of mixed metal carbonates $\left(\mathrm{MCO}_{3},\left(\mathrm{M}=\mathrm{Mn}_{x} \mathrm{Ni}_{y} \mathrm{Co}_{z}\right)\right)$. Then, the solid-state reaction of metal carbonates with lithium hydroxide was carried out. Finally, precursors obtained were annealed at $480^{\circ} \mathrm{C}(6 \mathrm{~h})$ and $900^{\circ} \mathrm{C}(12 \mathrm{~h})$.

The samples were characterized by scanning electron microscopy (SEM) using NVision-40 (Carl Zeiss) microscope. The powder X-ray diffraction (XRD) were collected in the $\Theta / 2 \Theta$ scan mode, $0.02^{\circ}$ scan step in the $2 \Theta$ range of $5^{\circ}-80^{\circ}$ using a Bruker D8 Advance diffractometer (Cu Ka radiation, $\lambda=0.15418 \mathrm{~nm}, 45 \mathrm{kV} / 250 \mathrm{~mA}$ ) at room temperature. All electrochemical procedures were carried out using Neware CT3008W-5V10mA battery testing system in lithium coin-type half-cells CR2032. The positive electrodes were made as active material (Li-rich oxides synthesized) - 92 wt\%: polyvinylidene difluoride (Solef 5130, Solvay) in N-methyl-2pyrrolidone - $3 \mathrm{wt} \%$ : conductive additive (Super C65 Timcal) - $2 \mathrm{wt} \%$. The active mass amount of cathode material was $8-12 \mathrm{mg}$. The lithium foil was used as an anode, and two layers of Celgard 2325 were used as a separator, and so was TC-E918 (Tinci) as an electrolyte.

Galvanostatic cycling was performed as follows. At first, several forming cycles with electrochemical activation to $4.8 \mathrm{~V}$ were carried out; and then the samples were cycled in the required voltage range. $D_{L i+}$ was determined according to Equation (1), as introduced by Weppner [13,14], using GITT results.

$D_{L \mathrm{i}+}=\frac{4}{\pi \tau}\left(\frac{m V_{m}}{M S}\right)^{2}\left(\frac{\Delta E_{s}}{\Delta E_{t}}\right)^{2}, \quad\left(\tau \triangleleft \triangleleft L^{2} / D_{L i+}\right)$

where:

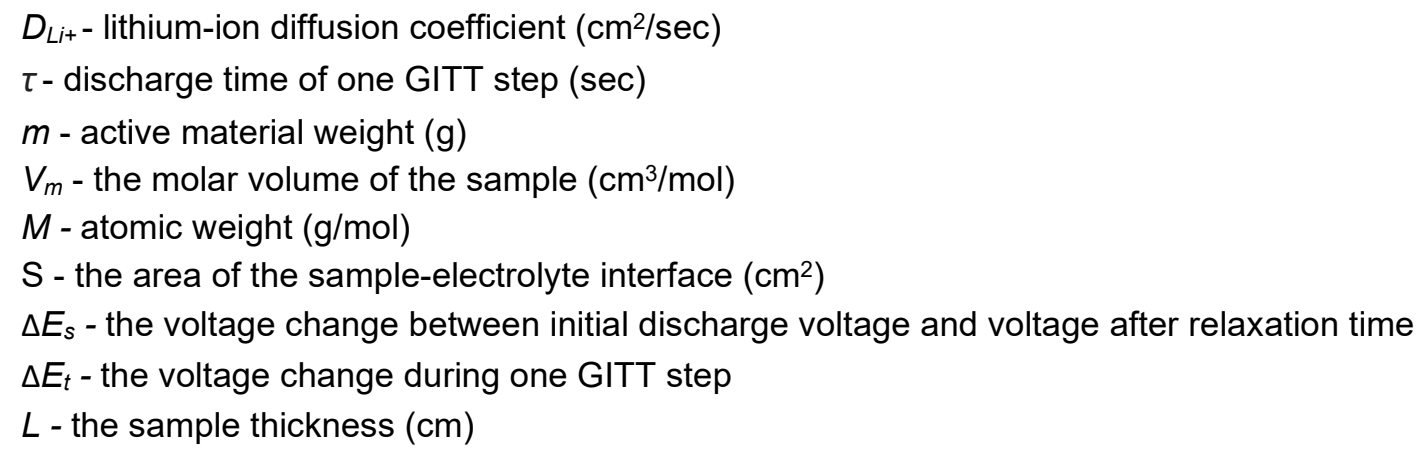

GITT was performed as follows: the cell was discharged at constant current during 30 min succeeded by current interruption (relaxation time) - $60 \mathrm{~min}$, which is sufficient to achieve an equilibrium voltage value. Such steps were repeated four times within a discharge, i.e. full discharge time was $120 \mathrm{~min}$. In terms of GITT results, we also estimated resistance values by the following procedure. At first, the voltage was measured at the end of each discharge step (U1). Then, the cut-off voltage was measured immediately after the current interruption (U2), and at the end of relaxation time (U3). The cell resistances were calculated from the voltage differences between $U 2$ and $U 1$ ( $\left.R_{\text {ohm. }}\right)$, and $U 3$ and $U 2\left(R_{\text {pol. }}\right)$ according to Equation (2) and Equation (3), respectively.

$R_{\text {ohm. }}=\frac{U 2-U 1}{I}$ 


$$
R_{p o l .}=\frac{U 3-U 2}{I}
$$

where:

$I$ - discharge current (A).

\section{RESULTS AND DISCUSSION}

The oxides are represented as powders composed of 6-12 $\mu \mathrm{m}$ agglomerates. The primary particles are 100$500 \mathrm{~nm}$ in size. The micrographs of the samples with the different compositions are shown in Figure 1.

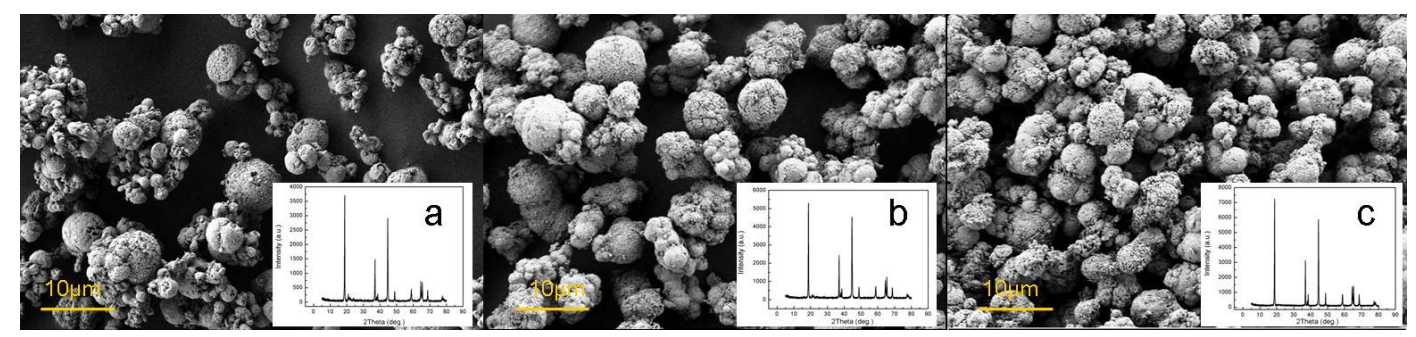

Figure 1 Micrographs and XRD patterns of (a) LMR50, (b) LMR35, and (c) LMR20 samples

The XRD patterns for all samples are also shown in Figure 1. Except for low-intensity peaks at $20^{\circ}-30^{\circ} 2 \Theta$, all peaks can be assigned to a trigonal phase $(R-3 m)$. The super-lattice peaks between $20^{\circ}$ and $30^{\circ}$ Characterize cation lithium ordering in transition metal layers that indicates the presence of the monoclinic phase $(C 2 / m)$ in our samples. Figure $2 \mathrm{a}$ shows the cycling behavior for all oxides in $2.5-4.8 \mathrm{~V}$ voltage range.
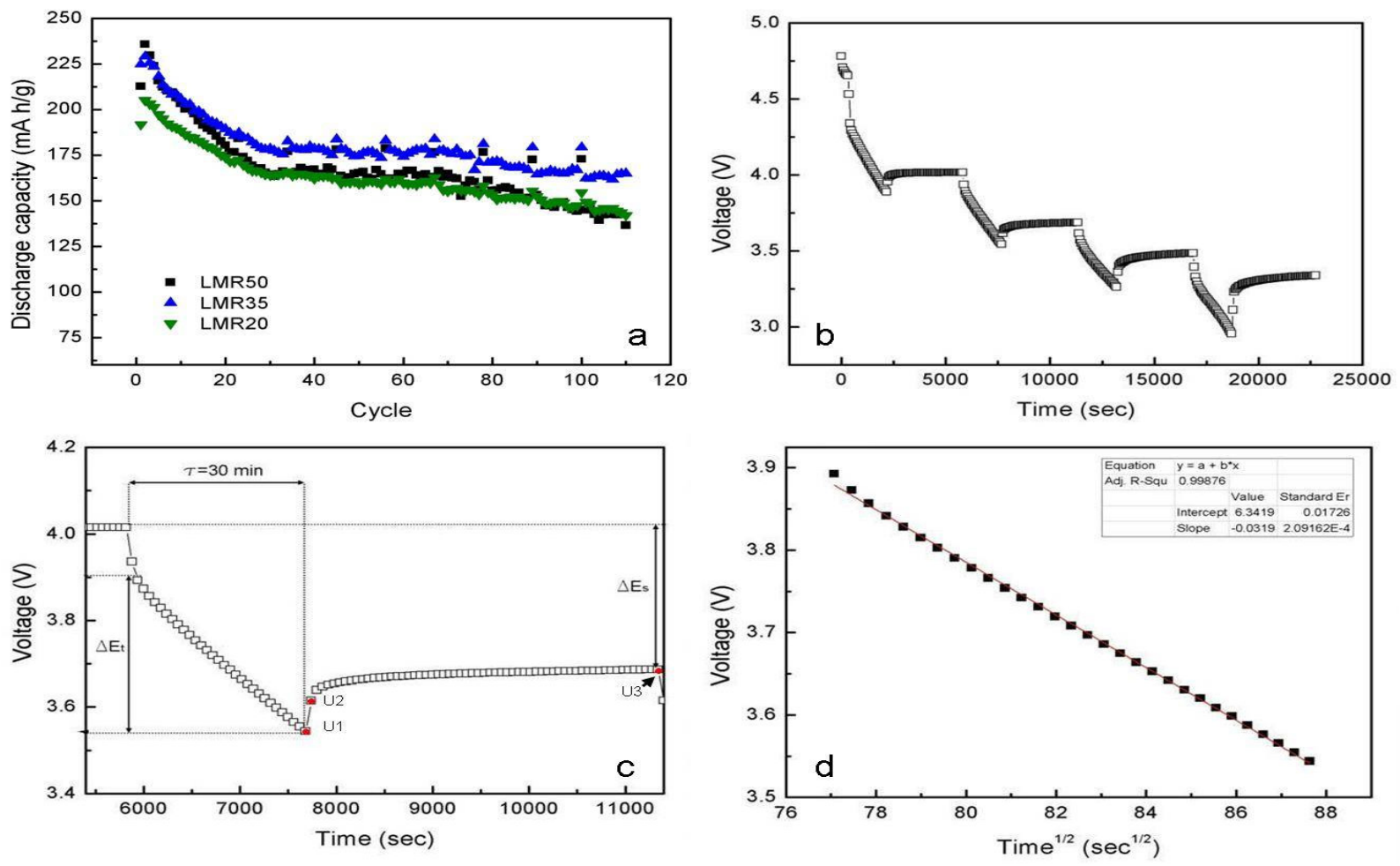

Figure 2 (a) Cycling of the samples, (b) GITT for the $1^{\text {st }}$ discharge of LMR50, (c) the $2^{\text {nd }}$ step of the $1^{\text {st }}$ discharge of LMR50, (d) linear fit for Voltage vs. $\sqrt{T i m e}$ dependence. The voltage range is $2.5-4.8 \mathrm{~V}$, and current density is $100 \mathrm{~mA} \mathrm{~h} / \mathrm{g}$. 
The intermittent titration was carried out at every tenth discharge cycle, which led to an increase in the capacity values in this cycle (Figure 2a). The difference in the discharge capacities obtained at galvanostatic cycling and in the GITT mode increases with increasing $\mathrm{Li}_{2} \mathrm{MnO}_{3}$ content in the Li-rich oxide. Figure $\mathbf{2} \mathbf{b}$ shows the discharge GITT curve for the $1^{\text {st }}$ cycle of LMR50. In Figure 2c, with the $2^{\text {nd }}$ step of LMR50 $1^{\text {st }}$ discharge as an example we show how to determine $\Delta E_{s}, \Delta E_{t}$ values for $D_{L i+}$ according to Equation (1), and U1, U2, U3 values for resistance calculation according to Equations $(2,3)$. Since dependence voltage from the square root of time for discharge steps is well-linearized, Equation (1) can be validly used for calculations of $D_{L i+}$.

The dependences of $D_{\text {Li+ }}$ (on log scale) on voltage during discharge in different cycles are presented in Figure 3. In the $1^{\text {st }}$ and $12^{\text {th }}$ cycles for LMR50, a decrease of $D_{L i+}$ is observed. Then, with increasing the cycle number, the diffusion coefficient increases (Figures 3a-d). Other behavior is characteristic of LMR20 and LMR35 samples.
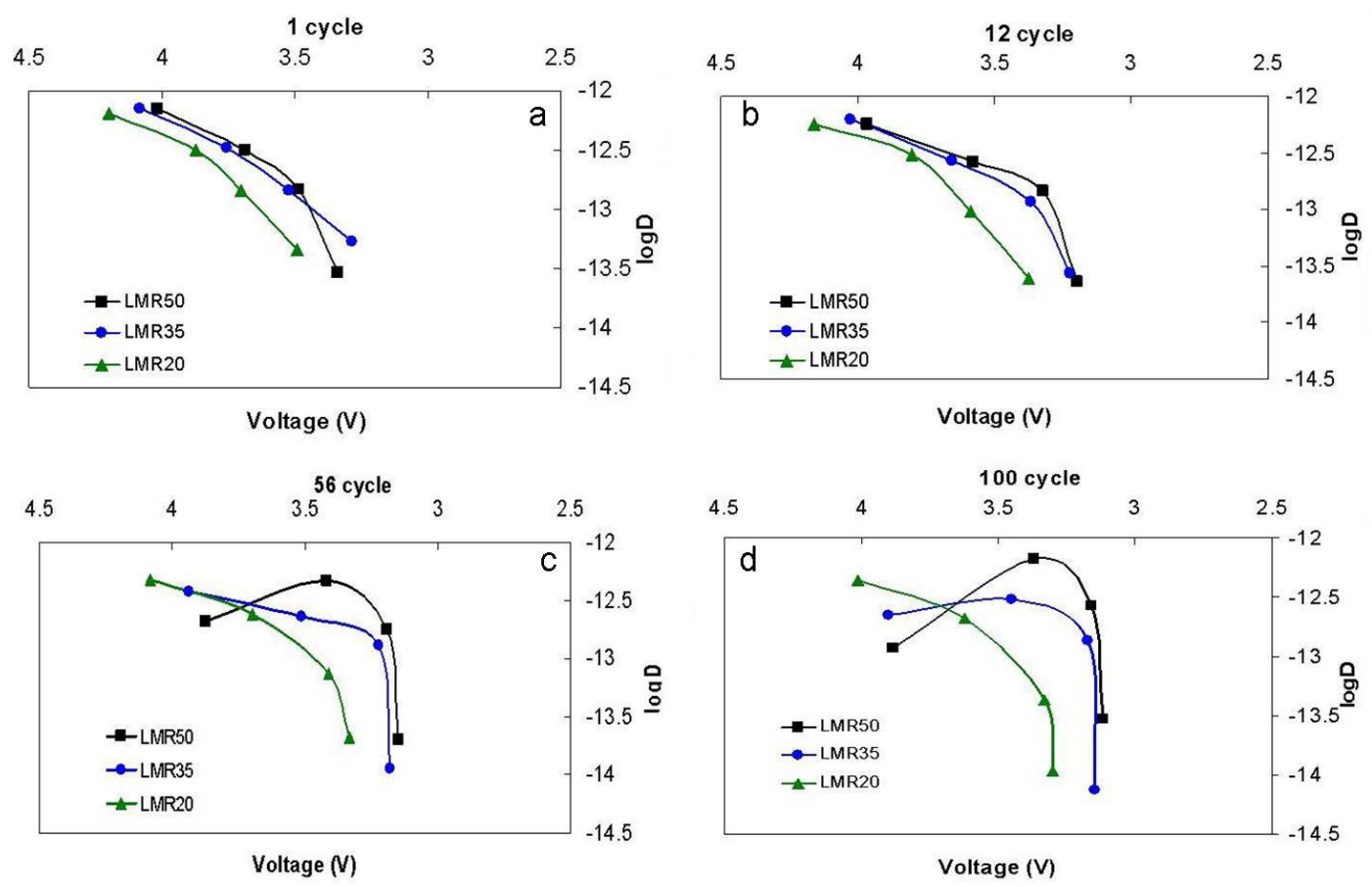

Figure 3 Dependence of lithium diffusion coefficient on voltage: (a) at $1^{\text {st }}$ cycle, (b) at $12^{\text {th }}$ cycle, (c) at $56^{\text {th }}$ cycle, (d) at $100^{\text {th }}$ cycle during GITT mode discharge (2.5-4.8 V).

Diffusion coefficients decrease from cycle to cycle for these samples, but a decrease in $D_{L i+}$ for LMR35 in the last cycles is not so considerable. For instance, the $D_{L i+}$ at 100 cycle differs by a factor of three (from $D_{L i+}$ at 56 cycle) for LMR20 and by a factor of two for LMR35.

From the results obtained and literature data [15,16], it is assumed that the Li-rich oxide structure has transformed into a spinel-like phase during long cycling. This transformation leads to a voltage decay and $D_{L i+}$ decrease. However, the authors [17] report that the spinel phase has 3-dimensional diffusion channels, which may benefit rate capability and lithium diffusion. At the same time, this can negatively influence on discharge capacity due to the loss of contact between different phases as a result of the structural transformation. The changes in the ohmic and polarization resistances within one cycle and from cycle to cycle are shown in Figure 4. The ohmic resistances slightly change during cycling for all the samples. At the same time, polarization resistances of the samples change in different ways from cycle to cycle, and especially within each cycle. Sample LMR35 shows small changes within a cycle (except the first 12 cycles). At long cycling, the resistance of LMR50 decreases within a cycle, and the resistance of LMR20 considerably increases. 
Considerable resistance changes within a cycle can be indicative of a great phase inhomogeneity in a composite, and vice versa better homogeneity and only insignificant $D_{L i+}$ decreasing with cycling observed for LMR35 can have a positive impact on both cycling and discharge capacity of the oxide.
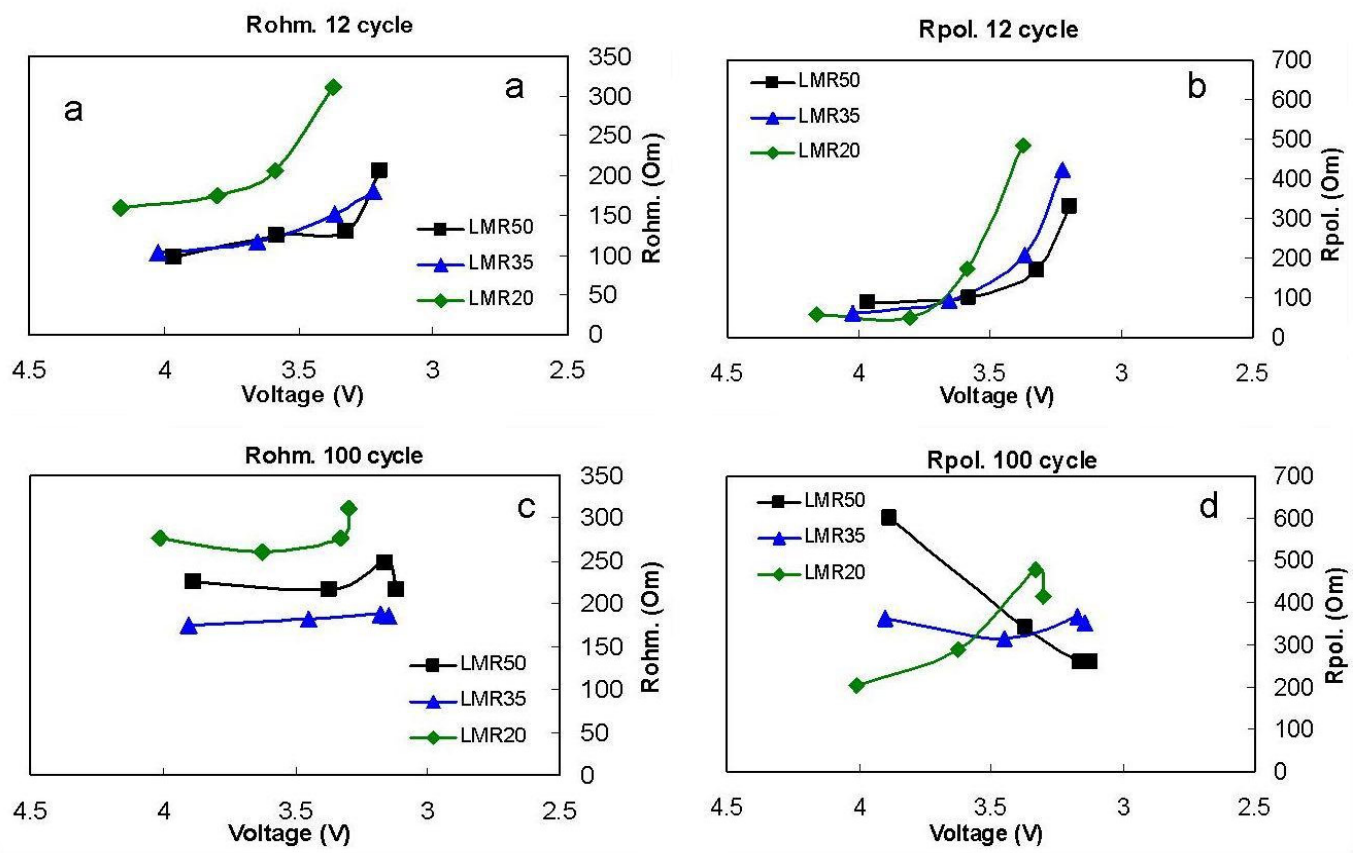

Figure 4 Dependence of $R_{\text {ohm. }}$ (a) at $12^{\text {st }}$ cycle, (b) $R_{\text {pol. }}$ at $12^{\text {st }}$ cycle, (c) and $R_{\text {ohm. }}$ at $100^{\text {st }}$ cycle, (d) $R_{\text {pol. }}$ at $100^{\text {st }}$ cycle on voltage during GITT mode discharge $(2.5-4.8 \mathrm{~V})$.

\section{CONCLUSION}

$\mathrm{Li}$-rich oxides with different $\mathrm{Li}_{2} \mathrm{MnO}_{3}$ content are synthesized by the coprecipitation method. These oxides are considered as positive electrode materials for LIBs. XRD patterns show that all the samples are composites on the basis of trigonal $(R-3 m)$ and monoclinic $(C 2 / m)$ phases. Galvanostatic cycling with GITT mode at each tenth discharge cycle is carried out in the voltage range 2.5-4.8 V. The relationship between the cycling behavior, lithium diffusion coefficient, and the cell resistances of the oxides is studied. The $D_{L i+}$ and resistance values after the $50^{\text {th }}$ cycle for the best-cycling sample (LMR35) are shown to change poorly, i.e. the structure of this compound is more stable. This $0.35 \mathrm{Li}_{2} \mathrm{MnO}_{3} \cdot 0.65 \mathrm{LiMn}_{1 / 3} \mathrm{Ni}_{1 / 3} \mathrm{Co}_{1 / 3} \mathrm{O}_{2}$ composition is optimal for having good electrochemical performance in spite of structural transformation to spinel-phase and voltage decay during long cycling in a wide voltage range.

\section{ACKNOWLEDGEMENTS}

The work was supported by the Russian Science Foundation, Grant \# 17-13-01424.

\section{REFERENCES}

[1] ROZIER, P and TARASCON, J. M. Review - Li-Rich Layered Oxide Cathodes for Next-Generation Li-Ion Batteries: Chances and Challenges. Journal of The Electrochemical Society. 2015. vol. 162, no. 14, pp. A2490A2499.

[2] THACKERAY, M.M., WOLVERTON, C. and ISAACS, E. D. Electrical energy storage for transportation approaching the limits of, and going beyond, lithium-ion batteries. Energy \& Environment Science. 2012. vol. 5, pp. 7854-7863. 
[3] THACKERAY, M.M., KANG, S.-H., JOHNSON, C. S., VAUGHEY, J. T., BENEDEK, R. and HACKNEY, S. A. Li2MnO3-stabilized LiMO2 (M = Mn, Ni, Co) electrodes for lithium-ion batteries. Journal of Materials Chemistry. 2007. vol. 17, pp. 3112-3125.

[4] JOHNSON, C. S., LI, N, LEFIEF, C. and THACKERAY, M.M. Anomalous capacity and cycling stability of $\mathrm{xLi}_{2} \mathrm{MnO}_{3} \cdot(1-\mathrm{x}) \mathrm{LiMO}_{2}$ electrodes $(\mathrm{M}=\mathrm{Mn}, \mathrm{Ni}, \mathrm{Co})$ in lithium batteries at $50{ }^{\circ} \mathrm{C}$. Electrochemistry Communications. 2007. vol. 9, pp. 787-795.

[5] THACKERAY, M.M., KANG, S.-H., JOHNSON, C. S., VAUGHEY, J. T. and HACKNEY, S. A. Comments on the structural complexity of lithium-rich $\mathrm{Li}_{1+{ }_{\mathrm{x}}} \mathrm{M}_{1-\mathrm{x}} \mathrm{O}_{2}$ electrodes $(\mathrm{M}=\mathrm{Mn}, \mathrm{Ni}, \mathrm{Co})$ for lithium batteries. Electrochemistry Communications. 2006. vol. 8, pp. 1531-1538.

[6] ZHENG, J., MYEONG, S., CHO, W., YAN, P., XIAO, J., WANG, C., CHO, J. and ZHANG, J.-G. Li- and Mn-Rich Cathode Materials: Challenges to Commercialization. Advanced Energy Materials. 2017. vol. 7, pp. 1601284.

[7] BETTGE, M., LI, Y., GALLAGHER, K., ZHU, Y., WU, Q., LU, W., BLOOM, I. and ABRAHAM, D. P. Voltage Fade of Layered Oxides: Its Measurement and Impact on Energy Density. Journal of The Electrochemical Society. 2013. vol. 160, no. 11, pp. A2046-A2055.

[8] ZHENG, J., SHI, W., GU, M., XIAO, J., ZUO, P., WANG, C. and ZHANG, J.-G. Electrochemical Kinetics and Performance of Layered Composite Cathode Material $\mathrm{Li}\left[\mathrm{Li}{ }_{0.2} \mathrm{Ni}_{0.2} \mathrm{Mn}_{0.6}\right] \mathrm{O}_{2}$. Journal of The Electrochemical Society. 2013. vol. 16, no. 3, pp. 100-121.

[9] IVANISHCHEV, A. V., CHURIKOV, A. V. and IVANISHCHEVA, I. A. Approaches to the investigation of lithium transport in intercalation electrodes based on thin film structures and multiphase composites. Electrochemical Energetic. 2016. vol. 160, no. 11, pp. A2212-A2219

[10] PECHEN, L. S., MAKHONINA, E. V., RYMYANTSEV, A. M., KOSHTYAL, Yu. M., VOLKOV, V. V., GOLOVESHKIN, A. S., PERVOV, V. S. and EREMENKO, I. L. Influence of the composition on the electrochemical properties of cathode materials $\mathrm{xLi}_{2} \mathrm{MnO}_{3} \cdot(1-\mathrm{x}) \mathrm{LiMn}_{1 / 3} \mathrm{Ni}_{1 / 3} \mathrm{Co}_{1 / 3} \mathrm{O}_{2}$ for lithium-ion batteries. Russian Chemical Bulletin. vol. 68, no. 2, pp. 293-300.

[11] MAKHONINA, E. V., MEDVEDEVA, A. E., DUBASOVA, V. S., VOlKOV, V. V., POLITOV, Yu. A., EREMENKO, I. $\mathrm{L}$. A new coating for improving the electrochemical performance of cathode materials. International Journal of Hydrogen Energy. 2016. vol. 41, pp. 9901-9907.

[12] PECHEN, L. S., MAKHONINA, E. V., RYMYANTSEV, A. M., KOSHTYAL, Yu. M., PERVOV, V. S. and EREMENKO, I. L. Effect of the Synthesis Method on the Functional Properties of Lithium-Rich Complex Oxides

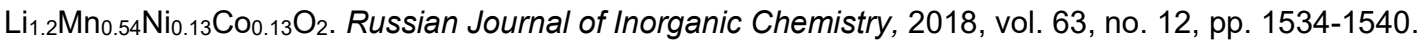

[13] WEPPNER, W. and HUGGINS, R. A., Determination of the kinetic parameters of mixed-conducting electrodes and application to the system Lis Sb. Journal of The Electrochemical Society. 1977. vol. 124, no. 10, pp. 15691578.

[14] WEN, C. J., BOUKAMP, B. A., HUGGINS R. A. and WEPPNER, W. Thermodynamic and mass transport properties of „Li-Al“. Journal of The Electrochemical Society. 1979. vol. 126, no. 12, pp. 2258-2266.

[15] ATES, M. N., JIA, Q, SHAH, A., BUSHAINA A., MUKERJEE, S. and ABRAHAM, K. M. Mitigation of Layered to Spinel Conversion of a Li-Rich Layered Metal Oxide Cathode Material for Li-lon Batteries. Journal of The Electrochemical Society. 2014. vol. 161, no. 3, pp. A290-A301.

[16] AMALRAJ, F., TALIANKER, M., MARKOVSKY, B., SHARON, D., BURLAKA L., SHAFIR G., ZINIGRAD E., HAIK, O., AURBACH, D., LAMPERT, J., SCHULZ-DOBRICK, M. and GARSUCH, A. Study of the Lithium-Rich Integrated Compound $\mathrm{xLi}_{2} \mathrm{MnO}_{3}(1-\mathrm{x}) \mathrm{LiMO}_{2}$ (x around 0.5; $\mathrm{M}=\mathrm{Mn}, \mathrm{Ni}, \mathrm{Co} ; 2: 2: 1$ ) and Its Electrochemical Activity as Positive Electrode in Lithium Cells. Journal of The Electrochemical Society. 2013. vol. 160, no. 2, pp. A324A337.

[17] SOHG, B., LIU, Z., LAI, M. O., LU, L. Structural evolution and the capacity fade mechanism upon long-term cycling in Li-rich cathode material. Physical Chemistry Chemical Physics. 2012. vol. 14, pp. 12875-12833. 